\title{
Sul rapporto tra luce e coscienza: messaggio religioso e recenti approfondimenti della fisica contemporanea
}

\author{
Paolo Di Sia ${ }^{1-3}$ \\ ${ }^{1}$ University of Padova, School of Science and School of Medicine, Via Jappelli 1, \\ I-35121 Padova, Italy \\ ${ }^{2}$ Free University of Bozen-Bolzano, Faculty of Science and Technology, Piazza Università 5, \\ I-39100 Bozen-Bolzano, Italy \\ ${ }^{3}$ E-mail / Webpage:paolo.disia@gmail.com; www.paolodisia.com
}

\begin{abstract}
Tutte le grandi religioni hanno utilizzato la luce come simbolo di trascendenza e caratteristica della divinità, hanno parlato di "scintilla divina che è in noi". La luce indica la vita; il simbolo della luce pervade la Bibbia dalla prima all'ultima pagina, è il principio della creazione. Dio è stato chiamato in vari modi, ma la luce è la metafora utilizzata per parlare della Sua natura. Dal punto di vista della fisica, la luce è un'onda elettromagnetica; la forza elettromagnetica è una delle quattro forze fondamentali ad oggi conosciute. Nelle teorie quantistiche sulla coscienza, essa è considerata una proprietà fondamentale dell'universo. Recenti approfondimenti considerano il nostro universo fisico come apparso da una transizione del tipo "transizione di fase" da un universo a 10 dimensioni spazio-temporali. La coscienza verrebbe creata dal campo elettromagnetico in relazione al gruppo di simmetria $\mathrm{SU}(6) \times \mathrm{U}(1)$. Il cervello umano viene concepito come organo di interfaccia che riceve informazioni, elemento di interferenza di dati in arrivo e di dati già esistenti (la memoria del soggetto).
\end{abstract}

Parole chiave: Coscienza, Luce, Forza elettromagnetica, Universo, Fisica teorica, Religioni, Bibbia, Dio.

\section{Riferimenti bibliografici}

1. Allen J.P., Middle Egyptian: An Introduction to the Language and Culture of Hieroglyphs, Cambridge: Cambridge University Press (2000).

2. Doniger W., Brahmā, in: Encyclopedia of Religion, vol. 2, New York: Macmillan (2005).

3. Magris A., Il manicheismo. Antologia dei testi, Brescia: Morcelliana (2000).

4. Puech H.C., Rudolph K., Doresse J., Gnosticismo e Manicheismo, in: Puech H.C. (Ed.), Storia delle Religioni, vol. VIII, Roma-Bari: Laterza (1988).

5. Hirtenstein S., The unlimited mercifier: the spiritual life and thought of Ibn 'Arabi, Oxford: Anqa publishers (1999).

6. Transfiguration e Mount Thabor, in: Catholic Encyclopedia, New York: Encyclopedia Press (1913).

7. Byrne M., The Names of God in Judaism, Christianity and Islam: A Basis for Interfaith Dialogue, London-New York: Continuum (2007).

8. Ravasi G., Maggioni B. (Eds), La Bibbia. Via verità e vita. Nuova versione ufficiale della CEI, Cinisello Balsamo: Edizioni San Paolo (2012).

9. AA.VV., SACRA BIBBIA CEI versione 1974, $3^{\text {a }}$ ed., edizioni cei (1988).

10. Mazzoldi P., Nigro M., Voci C., Fisica: Volume 1, Napoli: Edises (2001).

11. Mazzoldi P., Nigro M., Voci C., Fisica: Volume 2, Napoli: Edises (2001).

12. Picasso L.E., Lezioni di meccanica quantistica, $2^{\text {a }}$ ed., Pisa: ETS (2015). 
13. Di Sia P., $D=4, N=1$ supergravity in superspace: general overview and technical analysis, World Scientific News, WSN 94(1), 1-7 (2018).

14. Di Sia P., Exciting Peculiarities of the Extreme Physics, Journal of Physics: Conference Series, 442(1), 012068 (6 pp.) (2013).

15. Kumar Bhadra N., The Complex Quantum and Classical Pseudo-Tachyonic Universe, IOSR Journal of Mathematics (IOSR-JM), 8(3), 15-32 (2013).

16. Di Sia P., Spazi di Calabi-Yau e teorie di stringa, Periodico di Matematiche, VIII, 6(3), 49-59 (2006).

17. Kumar Bhadra N., Di Sia P., Mind and consciousness as created by electromagnetic force, International Journal of Applied and Advanced Scientific Research (IJAASR), 4(1), 1-6 (2019). doi: http://doi.org/10.5281/zenodo.2573101.

18. Dong L., Zheng Y., Li Z.Y., Li G., Lin L., Modulating effects of on-line low frequency electromagnetic fields on hippocampal long-term potentiation in young male Sprague-Dawley rat, Journal of Neuroscience Research, 96(11), 1775-1785 (2018).

19. Pockett S., The electromagnetic field theory of consciousness: a testable hypothesis about the characteristics of conscious as opposed to non-conscious fields, Journal of Consciousness Studies, 19(11-12), 191-223 (2012).

20. Kumar Bhadra N., The Complex Quantum-State of Consciousness, IOSR Journal of Applied Physics (IOSR-JAP), Ver. II, 9(1), 57-93 (2017).

21. McFadden J., The Conscious Electromagnetic Information (Cemi) Field Theory: The Hard Problem Made Easy?, Journal of Consciousness Studies, 9(8), 45-60 (2002).

22. Smith A.M., Messier C., Voluntary out-of-body experience: an fMRI study, Frontiers in Human Neuroscience, 8, 70 (2014).

23. van Lommel P., After life: a scientific approach to near-death experiences, $1^{\text {a }}$ ed., New York: HarperOne (2010).

24. Di Sia P., Mindfulness, Consciousness and Quantum Physics, World Scientific News, WSN 96, 25-34 (2018).

25. Di Sia P., Quantum Physics, Metaphysics, Theism: Interpretations, Ontologies, Theological Remarks, World Scientific News, 74, 106-120 (2017).

26. Di Sia P., On Quantum Physics, Metaphysics and Theism, in: Relations. Ontology and Philosophy of Religion, Sesto San Giovanni: Mimesis International (2018). https://www.amazon.co.uk/Relations-Ontology-Philosophy-Daniele-Bertini/dp/8869771261.

27. Kumar Bhadra K., The Origin of Consciousness in the Universe, IOSR Journal of Mathematics (IOSR-JM), Ver. III, 10(5), 53-68 (2014).

28. Vignolo R., Giangreco L., Luce e tenebre, in: Penna R., Perego G., Ravasi G., Temi Teologici della Bibbia, Cinisello Balsamo: San Paolo, 774-780 (2010).

29. AA.VV., Ries J., Ternes C.M. (Eds), Simbolismo ed esperienza della luce nelle grandi religioni, Milano: Jaca Book (1997). 